\title{
Peran Media Penjualan Terhadap Pendapatan E-Commerce Pada Usaha Mikro
}

\author{
Tri Lestari ${ }^{1}$, Dedi Damhudi ${ }^{2}$
}

${ }^{1}$ Universitas Bina Sarana Informatika

e-mail: tri.tle@bsi.ac.id

${ }^{2}$ Universitas Darma Persada

e-mail: dedi_damhudi@fe.unsada.ac.id

\begin{tabular}{ccc}
\hline Diterima & Direvisi & Disetujui \\
$02-09-2021$ & $19-09-2021$ & $20-09-2021$ \\
\hline
\end{tabular}

\begin{abstract}
Abstrak - Kemudahan dan rendahnya biaya dalam penggunaan internet saat ini telah menggeser cara manusia melakukan transaksi. Pergeseran dalam bertransaksi tersebut tidak hanya pada cara pembayaran, tetapi juga pada cara pembelian yang kini banyak dilakukan dengan menggunakan sistem online. Makalah ini membahas bagaimana beberapa media penjualan online mempengaruhi pendapatan e-commerce terbatas pada usaha mikro yang berpenghasilan kurang dari Rp. 300.000.000,- (tiga ratus juta Rupiah) per tahun. Media penjualan online yang digunakan sebagai variabel independen adalah website, marketplace/digital platform, media sosial, dan pesan singkat. Menggunakan data sekunder dari Badan Pusat Statistik di Indonesia, makalah ini mengkaji dan menganalisis data dengan metode penelitian kuantitaif dan menggunakan regresi berganda sebagai uji statistik. Hasil penelitian menunjukkan bahwa website, marketplace/digital platform, media sosial, dan pesan singkat sebagai variabel independen memiliki pengaruh yang signifikan terhadap pendapatan e-commerce usaha mikro secara paralel. Berbeda dengan variabel website, marketplace/digital platform, dan variabel pesan singkat yang memiliki pengaruh signifikan secara parsial terhadap pendapatan $e$-commerce usaha mikro, variabel media sosial tidak memiliki pengaruh secara parsial.
\end{abstract}

Kata kunci : media penjualan, pendapatan e-commerce, usaha mikro

\begin{abstract}
The ease and the low cost of using the internet today have shifted the way humans do transactions. The shifting in transactions not only how to make payments, but also how to purchase something are now mostly done using the online system. The paper concern how some online selling media affect the e-commerce revenue limited in micro-enterprises that have earned less than Rp. 300,000,000,- (three hundred million Rupiah) per year. The online selling media used as independent variables are website, marketplace/digital platform, social media, and short messages. Using secondary data from the central bureau of statistics in Indonesia, this paper reviewed and analyzed the data with quantitative research methods and used a multiple regression as the statistical test. The results showed that the independent variables of website, marketplace/digital platform, social media, and short messages as independent variables had a significant influence on the e-commerce revenue of micro-enterprises in parallel. In contrast to the variables of website, marketplaceldigital platform, and short messages variable had a significant effect partially on micro-business e-commerce income, the variable of social media does not have a partial influence.
\end{abstract}

Keywords : e-commerce revenue, selling media, micro enterprises

\section{PENDAHULUAN}

Dalam melakukan suatu usaha, tentunya setiap pelaku usaha memiliki strategi agar dapat unggul dan bertahan pada usaha yang digelutinya. Strategi yang sering dilakukan dalam penjualan atau pemasaran secara teori adalah strategi marketing mix yang mana istilah ini digunakan pertama kali oleh Neil Borden, namun istilah ini menjadi terkenal setelah disederhanakan oleh Jerome McCharty yang dalam (Akhmad, 2014) strategi marketing mix (bauran pemasaran terdiri dari) $4 \mathrm{P}$ terdiri dari:
1. Product (Produk) merupakan semua jenis barang atau jasa yang ditawarkan oleh para pelaku usaha dalam rangka memenuhi kebutuhan serta keinginan dari calon pembeli, hal yang termasuk dalam keragaman produk adalah mutu, desain, merk, kemasan, dimensi, pelayanan, garansi, dan imbalan.

2. Price (Harga) adalah nilai atau jumlah yang diberikan atau dibayarkan oleh pembeli atas produk atau jasa yang dibelinya dengan ketentuan yang diberikan oleh penjual, termasuk di dalamnya adalah diskon yang diberikan oleh 
penjual ataupun jenis pembayaran dan periode pembayaran.

3. Place merupakan saluran distribusi yng dipilih oleh pelaku usaha atau penjual untuk menawarkan produk dan jasanya, diantaranya adalah tempat untuk menjual produk yang dapat berupa toko fisik maupun toko non fisik (toko online).

4. Promotion merupakan jenis dari komunikasi yang dilakukan penjual untuk meyakinkan calon pembeli atas produk atau jasa yang ditawarkan.

Variabel Place (saluran distribusi) merupakan variable yang sangat penting untuk dipertimbangkan dalam melakukan penjualan produk atau jasa, kesalahan dalam pemilihan saluran distribusi akan memiliki dampak yang berkepanjangan bagi suatu usaha. Variasi saluran distribusi semakin berkembang seiring dengan berkembangnya teknologi. Begitupun perkembangan teknologi berupa jaringan internet yang semakin mudah di akses oleh masyarakat.

Penggunaan jaringan internet saat ini bukanlah suatu hal yang eksklusif lagi bagi masyarakat Indonesia khususnya bagi mereka yang tinggal di daerah perkotaan, walaupun penggunaan jaringan internet masih merupakan hal yang tidak mudah didapat bagi wilayah tertentu di Indonesia yang memiliki ketersediaan jaringan internet terbatas. Begitu juga dengan kegiatan penjualan dan pembelian, dengan adanya kemajuan, kemudahan dan ketersediaan jaringan internet saat ini tentunya memberikan peningkatan yang positif terhadap kegiatan tersebut.

Kegiatan usaha yang semakin akrab dengan internet, semakin menumbuhkan banyak masyarakat yang ingin memiliki usaha sendiri sehingga semakin bertambah usaha-usaha kecil yang menjual produk dan jasanya secara online. Penjualan melalui jaringan internet merupakan perluasan saluran distribusi yang diakibatkan oleh kemajuan teknologi, penjualan melalui perangkat electronic commerce ini juga dapat dilakukan dengan menggunakan berbagai macam media, seperti website, marketplaceldigital platform, media sosial, pesan singkat, dan media lainnya. Hal ini tentu saja sangat menarik untuk dilakukan penelitian apakah salurah distribusi yang dilakukan melalui jaringan internet oleh para pelaku usaha adalah saluran distribusi yang menjanjikan dan dapat dijadikan saluran distribusi utama, apalagi dengan adanya pandemik COVID-19 seperti saat ini dimana semua hal dilakukan di rumah dengan menggunakan fasilitas jaringan internet.

Penelitian mengenai variable Place (saluran distribusi) ini dilakukan dengan menggunakan data sekunder, yang diambil dari publikasi Badan Pusat Statistik berdasarkan hasil survei yang telah dipublikasikan dengan judul "Statistik E-Commerce 2020". Responden survei yang diberikan pertanyaan oleh tim penyusun buku dari Badan Pusat Statistik adalah para pelaku Usaha Mikro, Kecil, dan Menengah sebanyak 16.277 sampel dari 34 provinsi yang ada di seluruh Indonesia. Pelaku usaha yang menjadi target responden adalah pelaku usaha yang dalam menjalankan bisnisnya menggunakan jaringan internet, yaitu melakukan penjualan barang dan/atau jasa dengan menerima pesanan yang bersumber dari media penjualan melalui e-commerce selama kurun waktu tahun 2019. Berdasarkan hasil survei BPS (Luthfi et al., 2021) tersebut, 71.18 persen responden memiliki usaha yang melakukan penjualan melalui jaringan internet dan sudah dilaksanakan dalam jangka waktu tiga tahun terakhir yaitu tahun 20162019, dan terdapat 26.90 persen merupakan usaha yang sudah melakukan penjualan melalui media $e$ commercial sejak tahun 2010-2016, sedangkan sisanya sebanyak 1.92 persen merupakan usaha yang mulai melakukan penjualan melalui e-commerce sebelum tahun 2010 .

Pendapatan e-commerce yang digunakan sebagai variable dependen pada penelitian ini terbatas pada responden dengan kategori usaha mikro, yaitu responden yang memiliki pendapatan melaluimecommerce di bawah Rp. 300.000.000,- (tiga ratus juta Rupiah) per tahun dengan mempertimbangkan bahwa berdasarkan hasil survei yang dilakukan oleh Badan Pusat Statistik, pelaku usaha e-commerce terbanyak adalah pelaku usaha yang memiliki pendapatan di bawah Rp. 300,000,000,- (tiga ratus juta Rupiah) per tahunnya. Sedangkan variable independen yang digunakan sebagian variable pengujian adalah website, marketplace/digital platform, media sosial, dan pesan instan.

Penelitian sebelumnya dilakukan oleh (Ayuni et al., 2019) untuk mengetahui adanya hubungan antara pemakaian media digital terhadap tingkatan penjualan produk kuliner kemasan di golongan wirausaha wanita di Kota Makassar dengan menggunakan metode penelitian kuantitatif regresi linier sederhana yang mana hasil dari penelitian tersebut adalah terdapat pengaruh yang positif serta signifikan antara pemakaian media digital terhadap tingkatan penjualan ialah sebesar 60,2\%, dimana Instagram merupakan media sosial yang paling banyak digunakan ialah sebesar 74, 1\%,. Penelitian yang dilakukan oleh (Hari, Moch Purwidiantoro et al., 2016) menunjukkan bahwa pemakaian media sosial tehadap pengembangan usaha kecil menengah (UKM) mampu meningkatkan volume penjualan hingga sebesar 10- 50\%, penelitian ini dilakukan dengan menggunakan metode kualitatif deskriptif.

Perbedaan penelitian ini dengan penelitian sebelumnya adalah penelitian sebelumnya hanya menggunakan satu variable independen yaitu variabel media sosial, data yang digunakan merupakan data primer dengan responden yang berada di suatu wilayah tertentu dan metode penelitian yang digunakan adalah regresi linier sederhana. Sedangkan penelitian ini menggunakan empat variabel independen, menggunakan data sekunder dengan responden dari 34 provinsi dengan metode penelitian regresi linier berganda. 


\section{Media Penjualan}

Media penjualan merupakan media yang digunakan oleh para pelaku usaha, dalam hal ini adalah pelaku usaha yang melakukan penjualan melalui e-commerce untuk menawarkan produk atau jasanya kepada calon pembeli.(Ayuni et al., 2019).

Dalam keberlangsungan usaha, media penjualan memiliki peranan yang penting. Pemilihan media penjualan haruslah benar-benar tepat agar produk atau jasa yang ditawarkan dapat merebut hati pembeli sehingga memutuskan untuk melakukan transaksi. Media penjualan melalui e-commerce merupakan jenis pasar persaingan yang sangat sempurna, dimana calon pembeli hanya dengan menggunakan media elektronik seperti handphone, laptop, dan komputer dapat mengetahui harga dari berbagai macam toko online dan melakukan pembelian atas produk atau jasa yang dicari sesuai dengan merk, spesifikasi dan uang yang dimiliki. Pencarian media penjualan e-commerce dapat dilakukan di rumah atau di manapun calon pembeli berada, asalkan memiliki akses internet dan gadget. Media penjualan e-commerce yang dimaksud adalah seperti Website, Shopee, Tokopedia, Facebook, Instagram, WhatsApp, dan lain sebagainya.

Secara spesifik, media penjualan yang digunakan dalam penelitian ini adalah media digital, menurut Blanchard dalam (Ayuni et al., 2019) bahwa pemakaian media digital dalam bisnis tidak hanya semata-mata dilakukan untuk aktivitas pemasaran saja, namun media digital ini dapat juga digunakan sebagai mekanisme komunikasi terintegrasi sehingga dapat memperkuat pengaruh dari setiap peran di dalam suatu organisasi dengan menggunakan kekuatan jejaring manusia dengan menggunakan suatu platform.

\section{Website}

Menurut (Trimarsiah \& Arafat, 2017), website merupakan kumpulan dari halaman-halaman web, yang biasanya terangkum dalam suatu domain atau subdomain, yang tempatnya terletak di dalam World Wide Website $(W W W)$ di internet. Sebuah halaman website merupakan dokumen yang ditulis dalam format HTML (Hyper Text Markup Language), yang dapat di akses setiap saat melalui HTTP (Hyper Text Transfer Protocol), yaitu protokol yang dapat mengirimkan informasi dari server web agar dapat ditampilkan kepada para pengguna melalui web broser.

Website merupakan media untuk memperkenalkan usaha berupa halaman yang dapat di akses menggunakan internet dan terdiri atas domain yang biasanya merupakan nama usaha, dan hosting sebagai tempat pengolahan data website. Pada website terdapat halaman-halaman yang menjelaskan mengenai usaha yang dilakukan, diantaranya adalah :

\section{Profil usaha.}

Pada halaman ini menjelaskan bagaimana riwayat usaha tersebut didirikan, visi dan misi, orangorang yang mendirikan usaha tersebut, pihak-pihak yang dapat dihubungi pada saat melakukan transaksi, saat pengajuan klaim produk, saat melakukan pembayaran, dan pihak-pihak lain yang berhubungan dengan proses jual-beli yang dilakukan pada halaman website tersebut. Halaman profil usaha merupakan halaman yang penting pada sebuah website, karena calon pembeli harus mengetahui kepada siapa mereka melakukan transaksi. Apakah mereka melakukan transaksi kepada pihak-pihak yang memiliki itikad baik, atau sebaliknya. Dalam hal ini, pelaku usaha wajib menerangkan serinci mungkin, agar calon pembeli merasakan keamanan dalam melakukan transaksi

\section{Profil produk.}

Halaman ini berisi etalase produk yang dijual, pada etelase tersebut sejatinya berisi penjelasan yang lengkap mengenai produk atau jasa yang dijual, baik itu berupa gambar, video, animasi, maupun keterangan mengenai produk secara rinci seperti ukuran berat, lebar, panjang, warna, material yang digunakan, cara perawatan produk, dan penjelasan lainnya.

\section{Cara melakukan pembelian.}

Dalam sebuah website, halaman yang berisi mengenai penjelasan cara melakukan pembelian produk atau jasa merupakan halaman yang penting dibuat, hal ini dilakukan agar calon pembeli tidak bingung saat akan melakukan pembelian pada website tersebut, terutama pembeli yang pertama kali berbelanja secara online. Karena seperti hal nya toko offline, dimana pembeli dan penjual bertemu secara langsung, setiap toko memiliki cara yang berbedabeda dalam menerapkan cara pembelian kepada pembeli. Ada toko yang menerapkan cara pembelian dengan menggunakan keanggotaan, atau pun cara pembelian yang tidak menggunakan keanggotaan.

\section{Cara melakukan pembayaran.}

Merupakan halaman yang memberikan penjelasan mengenai alur pembayaran yang dilakukan oleh calon pembeli. Cara melakukan pembayaran pada e-commerce biasanya dilakukan dengan menggunakan berbagai macam metode, seperti transfer melalui ATM, Indomaret, Alfamart, $e$-wallet, ataupun cara melakukan pembayaran dengan menggunakan internet banking, baik yang melalui bank yang sama ataupun melalui bank yang berbeda.

\section{FAQ (Frequent Ask Questions).}

Seringkali pembeli bingung atau ingin bertanya hal-hal yang ingin diketahuinya sebelum melakukan pembelian, bila pembelian dilakukan secara langsung mendatangi toko offline maka pembeli dapat menanyakan hal-hal yang ingin diketahuinya kepada pegawai yang saat itu bertugas di dalam toko, namun berbeda dengan pembelian melalui e-commerce dimana pegawai toko tidak dapat 
ditemukan, pembeli akan kesulitan untuk bertanya. Biasanya sebuah website yang professional sudah memiliki rangkuman dari pertanyaan-pertanyaan standar yang sering ditanyakan oleh calon pembeli. Pertanyaan-pertanyaan tersebut dicantumkan pada halaman $F A Q$ berserta jawabannya.

\section{Fitur Chat}

Fitur chat merupakan fitur yang penting dalam sebuah e-commerce. Walaupun terdapat halaman FAQ, namun banyak hal spesifik terkait dengan produk yang akan menjadi kepuasan bagi pembeli untuk menanyakan secara langsung kepada penjual. Hal-hal tersebut, dapat dilakukan dengan menggunakan fitur chat.

\section{Marketplace/Digital Platform}

Marketplace merupakan penyedia forum untuk banyak penjual, yang mana penjual-penjual tersebut dapat merepresentasikan katalog produk mereka dan melakukan perdagangan sebanyakbanyaknya untuk memenuhi kebutuhan pembeli (Grieger, 2003). Marketplace/digital platform juga merupakan media penjualan yang saat ini sangat ramai digunakan, baik oleh penjual maupun oleh pembeli. Marketplace yang dimaksud adalah seperti Shopee, Tokopedia, Bukalapak, Blibli, Lazada, dan lain sebagainya. Marketplace merupakan media yang sangat banyak digunakan oleh kalangan usaha untuk menawarkan produk atau jasanya, terutama usahausaha yang tidak terlalu besar, dan mereka yang baru memulai usaha. Walaupun pada kenyataannya saat ini, marketplace juga merupakan salah satu media penjualan yang menjadi sasaran utama para pengusaha-pengusaha besar, hal ini dapat dibuktikan dengan semakin bertambahnya toko-toko online pada marketplace yang merupakan official store.

\section{Media Sosial}

Media sosial merupakan media yang digunakan dengan menggunakan sistem dalam jaringan atau yang biasa disebut dengan media daring. (Akram \& Kumar, 2017) Media sosial merupakan platform online yang digunakan orang untuk membangun jaringan sosial ataupun ikatan sosial dengan orang lain yang mempunyai atensi, kegiatan, latar belakang, ataupun ikatan kehidupan nyata yang sama, baik secara individu ataupun karir Para pengguna dapat menggunakan media daring tersebut untuk dapat saling berbagi, saling berhubungan, dan saling berinteraksi secara virtual. Media daring yang biasanya digunakan adalah Facebook, Twitter, Instagram, dan lain sebagainya.

\section{Pesan Instan/Pesan Singkat}

Pesan singkat merupakan suatu sistem yang digunakan untuk mengirim dan menerima pesan secara cepat dengan menggunakan jaringan internet. Pesan singkat yang dikirimkan oleh para pengguna secara dua arah baik pengguna sebagai pengirim pesan maupun pengguna sebagai penerima pesan.
Komunikasi pesan singkat ini dilakukan secara cepat dan real time. Pesan singkat yang banyak digunakan saat ini adalah WhatsApp, Line, Telegram, dan media pesan singkat lainnya.

\section{E-Commerce}

E-commerce (electronic commerce) berdasarkan pada Organizations for Economic CoOperation and Development (OECD) 2009 (Luthfi et al., 2021) merupakan penjualan ataupun pembelian benda/jasa yang dilakukan lewat jaringan PC dengan sistem yang secara spesifik dirancang dengan tujuan menerima ataupun melaksanakan pesanan namun pembayaran serta pengiriman utama benda/jasa tidak selalu dilaksanakan secara online. Transaksi $e$ commerce bisa terjalin antar usaha, rumah tangga, perseorangan, instansi pemerintah, serta organisasi swasta ataupun publik yang lain.

\section{Pendapatan E-commerce}

Pendapatan E-commerce merupakan pendapatan yang dihasilkan oleh pelaku usaha dari penjualan produk/jasa melalui media penjualan $e$ commerce. Sedangkan menurut Undang-Undang No. 20 tahun 2008 pada pasal enam ayat satu, dua dan tiga (OJK, 2008) tentang pendapatan Usaha Mikro Kecil dan Menengah yang diklasifikasikan sebagai berikut

Tabel 1. Klasifikasi Kekayaan dan Pendapatan UMKM

\begin{tabular}{lll}
\hline \multirow{2}{*}{$\begin{array}{c}\text { Jenis } \\
\text { Usaha }\end{array}$} & \multicolumn{2}{c}{ Klasifikasi } \\
\cline { 2 - 3 } & $\begin{array}{l}\text { Kekayaan } \\
\text { Bersih }\end{array}$ & Pendapatan/tahun \\
\hline Mikro & $<$ Rp. 50Jt & < Rp. 300Jt \\
\hline \multirow{2}{*}{ Kecil } & Rp. 50jt - Rp. & Rp. 300jt - Rp. \\
\hline \multirow{2}{*}{ Menengah } & 500Jt & 2,5M \\
\hline Rp. 500Jt - & >Rp. 2,5M - Rp. \\
\hline
\end{tabular}

Sumber : Undang-Undang No. 20 tahun 2008 yang diolah (2021)

\section{Internet}

(Rustam, 2017) Internet merupakan komunikasi antar manusia dengan menggunakan jaringan komunikasi elektronik yang dapat terjadi disebabkan adanya koneksitas jaringan computer.

\section{Kerangka Berpikir}

Dengan berlandaskan latar belakang dan teori yang telah dijabarkan, maka dapat disimpulkan kerangka berpikir untuk penelitian ini adalah sebagai berikut : 


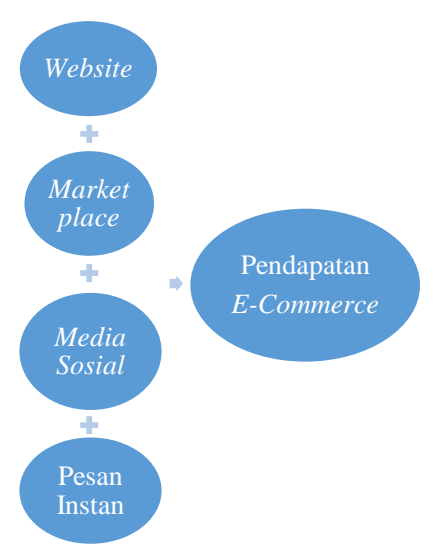

Sumber : Penelitian (2021)

Gambar 1 Kerangka Berpikir

\section{METODE PENELITIAN}

\section{Jenis Metode Penelitian}

Metode penelitian yang digunakan dalam penelitian ini merupakan metode kuantitatif dengan menggunakan uji statistik Multiple Regression atau Regresi Berganda dan uji F. Menurut Machfoedz dalam (Agung, 2020) sesuatu desain penelitian bisa dikatakan bermutu ataupun mempunyai ketepatan bila terpenuhi dua ketentuan, yaitu dapat digunakan guna menguji hipotesis (khusus bagi penelitian yang menggunakan metode kuantitatif analitik) serta mampu mengatur ataupun mengendalikan varian. Untuk melakukan uji asumsi klasik, alat uji yang digunakan adalah uji normalitas dan uji multikolinieritas. Sedangkan proses data yang dilakukan untuk melakukan pengujian dalam penelitian ini menggunakan aplikasi eviews

\section{Teknik Pengumpulan dan Data}

Menurut Trisliatanto dalam (Agung, 2020), proses pengumpulan informasi secara kuantitatif, diantaranya adalah data sekunder berupa informasi yang didapat dari lembaga ataupun institusi terpaut. Penelitian ini menggunakan data sekunder, dan data sekunder yang digunakan adalah data yang diambil dari publikasi Badan Pusat Statistik berdasarkan hasil survei yang sudah diterbitkan dengan judul "Statistik E-Commerce 2020".

\section{Teknik Analisis Data}

Analisis data ialah proses mengorganisasikan serta menyusunkan data ke dalam pola, jenis, serta satuan penjelasan dasar sehingga bisa ditemui tema serta bisa diformulasikan hipotesis kerja sebagaimana yang didasarkan oleh data (Agung, 2020).Teknik analisis data yang digunakan untuk dapat menjawab hipotesis penelitian ini adalah uji asumsi klasik normalitas, uji multikolinieritas, uji $\mathrm{F}$, dan uji validitas regresi berganda.

\section{Uji Asumsi Regresi Klasik}

Uji asumsi klasik merupakan syarat statistik yang wajib dipenuhi pada saat melakukan analisis regresi linear berganda (Eko et al., 2017). Uji asumsi klasik yang dipakai untuk penelitian ini adalah uji normalitas dan uji multikolinieritas. Uji normalitas dilakukan untuk melihat apakah data yang disajikan dalam suatu penelitian merupakan data yang memiliki distribusi normal ataukah data yang memiliki distribusi yang tidak normal. Sedangkan uji multikolinieritas dilakukan untuk melihat ada atau tidaknya masalah multikolinieritas pada model yang dilakukan prediksi.

\section{Uji F}

Uji F dimaksudkan untuk menguji apakah variabel-variabel independen secara bersama-sama berpengaruh signifikan terhadap variable dependen.

\section{Regresi Linier Berganda}

Analisis regresi berganda dilakukan untuk melihat apakah ada keterikatan antar variable independen yang jumlahnya lebih dari 1, dengan variabel dependen. Sehingga rumus persamaan regresi linier berganda untuk penilitian ini adalah sebagai berikut :

$$
\begin{array}{ll}
\mathrm{Y}=\alpha+\beta 1 \mathrm{X} 1+\beta 2 \mathrm{X} 2+\beta 3 \mathrm{X} 3+\beta 4 \mathrm{X} 4+\varepsilon \ldots . .(1) \\
\text { Keterangan : } & \\
\text { Variabel Y } & =\text { pendapatan } \text { e-commerce } \\
\text { Varaiabel X1 } & =\text { website } \\
\text { Variabel X2 } & =\text { marketplace/digital platform } \\
\text { Variabel X3 } & =\text { media sosial } \\
\text { Variabel X4 } & =\text { pesan instan } \\
\varepsilon & =\text { nilai residu }
\end{array}
$$

\section{HASIL DAN PEMBAHASAN}

\section{Uji Normalitas}

Uji normalitas dilakukan untuk melihat apakah data yang disajikan dalam suatu penelitian merupakan data yang memiliki distribusi normal ataukah data yang memiliki distribusi yang tidak normal.

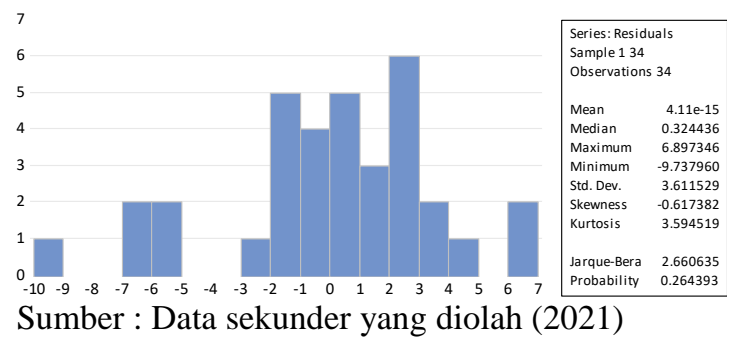

Gamber 2. Hasil Uji Normalitas

Pada histogram di atas terlihat bahwa nilai dari Jarque-Bera (JB) adalah sebesar 2.660635, sedangkan nilai pada table Chi square untuk 
penelitian ini adalah sebesar 48.6024 (nilai JB < nilai tabel Chi square atau $2.660635<48.6024)$.

Sedangkan pada nilai Probability ditampilkan nilai sebesar 0.264393 , sehingga nilai Probability $>\alpha$, atau $0.264393>0.05$.

Dengan melihat nilai Jarque-Bera dan Probability diatas, dapat disimpulkan bahwa data sekunder yang disajikan pada penelitian ini berdistribusi normal.

\section{Uji Multikolinieritas}

Menurut (Sukmono, 2014) dalam (Eko et al., 2017) varians parameter yang diestimasikan akan dapat lebih besar dari yang semestinya disebabkan karena adanya multikolinieritas, sehingga estimasi dari tingkat akurasi memjadi turun. Multikolinearitas merupakan suatu keadaan dimana adanya korelasi antara variabel independen atau antar variabel independen yang tidak memiliki sifat saling bebas. Besaran (quality) yang bisa dipakai untuk melakukan pendeteksian adanya multikolinearitas yaitu faktor inflasi ragam atau disebut juga dengan Variance Inflation Factor / VIF (Sriningsih et al., 2018). Masalah multikolinieritas yang serius diidentifikasikan dengan adanya nilai VIF yang lebih besar dari 10 (Ryan, 1997).

Tabel 2. Hasil Uji Multikolinieritas

Variance Inflation Factors

Sample: 134

Included observations: 34

\begin{tabular}{cccc}
\hline \hline & $\begin{array}{c}\text { Coefficient } \\
\text { Variable }\end{array}$ & $\begin{array}{c}\text { Uncentered } \\
\text { VIF }\end{array}$ & $\begin{array}{c}\text { Centered } \\
\text { VIF }\end{array}$ \\
\hline C & 326,1859 & 747,2157 & NA \\
Website & 0,116967 & 5,884623 & 2,325281 \\
Marketplace & 0,012962 & 16,38497 & 4,891026 \\
Mediasosial & 0,004792 & 60,79631 & 1,728156 \\
Pesaninstan & 0,022275 & 417,8326 & 2,499150 \\
\hline \hline
\end{tabular}

Sumber : Data sekunder yang diolah (2021)

Berdasarkan tabel 2 hasil uji multikolinieritas di atas, tercantum nilai centerd VIF pada masingmasing variabel independent yaitu: website 2.325281, marketplace/digital platform 4.891026, media sosial 1.728156, dan pesan instan sebesar 2.499150, menunjukkan nilai yang besarknya kurang dari 10 . Dengan demikian dapat dikatakan bahwa model yang diprediksi tidak teridentifikasi adanya multikolinieritas.

\section{Analisis Regresi Berganda}

Berikut ini adalah tabel 3 yang merupakan hasil analisis regresi berganda dari olah data sekunder menggunakan aplikasi eviews.
Tabel 3. Hasil Analisis Regresi Berganda

\begin{tabular}{|c|c|c|c|c|}
\hline \multicolumn{5}{|c|}{$\begin{array}{l}\text { Method: Least Squares } \\
\text { Sample: } 1 \\
34 \\
\text { Included Observations: } \\
34\end{array}$} \\
\hline Variable & Coefficient & $\begin{array}{c}\text { Std. } \\
\text { Error }\end{array}$ & $\begin{array}{c}t- \\
\text { Statistic } \\
\end{array}$ & Prob. \\
\hline $\mathrm{C}$ & 135,1933 & 18,06062 & 7,485531 & 0,0000 \\
\hline Website & $-1,065132$ & 0,342005 & 3,114378 & 0,0041 \\
\hline Marketplace & $-0,320405$ & 0,113851 & 2,814255 & 0,0087 \\
\hline Mediasosial & $-0,073166$ & 0,069226 & $1,056917^{-}$ & 0,2993 \\
\hline Pesaninstan & $-0,330461$ & 0,149247 & 2,214193 & 0,0348 \\
\hline \multirow{5}{*}{$\begin{array}{l}\text { R-squared } \\
\text { Adjusted R- } \\
\text { squared } \\
\text { S.E. of } \\
\text { regression } \\
\text { Sum } \\
\text { squared } \\
\text { resid } \\
\text { Log }\end{array}$} & 0,684316 & \multicolumn{2}{|c|}{ Mean dependent var } & 89,82618 \\
\hline & 0,640773 & \multicolumn{2}{|c|}{$\begin{array}{l}\text { S.D. dependent var } \\
\text { Akaike info }\end{array}$} & 6,427832 \\
\hline & 3,852557 & \multicolumn{2}{|c|}{ criterion } & 5,670404 \\
\hline & & & & \\
\hline & 430,4237 & \multicolumn{2}{|c|}{ Schwarz criterion } & 5,894869 \\
\hline likelihood & $-91,39687$ & \multicolumn{2}{|c|}{ Hannan-Quinn criter. } & 5,746953 \\
\hline \multirow{2}{*}{$\begin{array}{l}\text { F-statistic } \\
\text { Prob(F- } \\
\text { statistic) }\end{array}$} & 15,71597 & \multirow{2}{*}{\multicolumn{2}{|c|}{ Durbin-Watson stat }} & 2,055052 \\
\hline & 0,000001 & & & \\
\hline
\end{tabular}

Sumber : Data sekunder yang diolah (2021)

\section{Uji Koefisien Determinasi (Adjusted R2)}

Berdasarkan nilai coefficient pada adjusted $R$ square tabel 3, yaitu sebesar 0.640773, dapat disimpulkan bahwa 64.08 persen variabel independen mempengaruhi variable dependen, sisanya sebesar 35,92 persen dipengaruhi oleh variable independen lainnya.

\section{Uji F}

Menurut (Lind et al., 2014) dalam (Marita, 2015), uji F dibutuhkan untuk mengenali apakah terdapat pengaruh simultan dari seluruh variabel bebas yang diformulasikan terhadap variabel terikatnya. Dalam melakukan uji F, pengambilan keputusan didasarkan pada nilai Prob (F-statistic) yang tercantum pada hasil olah data tabel 3 .

\section{Hipotesis Statistik}

$\mathrm{H}_{0}$ : variabel-variabel independen yaitu website, marketplace, media sosial, dan pesan instan secara bersama-sama tidak berpengaruh signifikan terhadap variable dependen pendapatan e-commerce.

$\mathrm{H}_{1}$ : variabel-variabel independen yaitu website, marketplace, media sosial, dan pesan instan secara 
bersama-sama berpengaruh signifikan terhadap variable dependen e-commerce.

Dasar pengambilan keputusan :

Jika probabilitasnya (nilai sig) $>0.05$ atau $\mathrm{F}$ hitung < $\mathrm{F}$ table maka $\mathrm{H}_{0}$ diterima dan $\mathrm{H}_{1}$ ditolak.

Jika probabilitasnya (nilai sig) $<0.05$ atau $\mathrm{F}$ hitung $>$ $\mathrm{F}$ table maka $\mathrm{H}_{0}$ ditolak dan $\mathrm{H}_{1}$ diterima.

Keputusan :

1. Nilai Prob $(F$-statistic $)=0.000001<0.05$ maka $\mathrm{H}_{0}$ ditolak, yang berarti variabel-variabel independen secara bersama-sama berpengaruh signifikan terhadap variable dependen.

2. Nilai $p$-value variabel website $=0.041<0.05$, sehingga $\mathrm{H}_{0}$ ditolak dan $\mathrm{H}_{1}$ diterima yang berarti variabel independen website secara parsial berpengaruh signifikan dan positif terhadap variable pendapatan $e$-commerce.

Semakin tinggi penjualan melalui website, maka akan semakin tinggi pendapatan melalui $e$ commerce.

3. Nilai $p$-value variabel marketplace/platform digital $=0.0087<0.05$, sehingga $\mathrm{H}_{0}$ ditolak dan $\mathrm{H}_{1}$ diterima yang berarti variabel marketplace/platform digital secara parsial berpengaruh signifikan dan positif terhadap variabel pendapatan e-commerce.

Semakin tinggi penjualan melalui marketplace/platform digital, maka akan semakin tinggi pendapatan melalui e-commerce.

4. Nilai $p$-value variable media sosial $=0.2993>$ 0.05 , sehingga $\mathrm{H}_{0}$ diterima dan $\mathrm{H}_{1}$ ditolak yang berarti variabel media sosial secara parsial tidak berpengaruh signifikan terhadap variabel pendapatan $e$-commerce.

Semakin tinggi penjualan melalui media sosial maka tidak dapat disimpulkan akan semakin tinggi pula pendapatan melalui e-commerce.

5. Nilai $p$-value variable pesan instan $=0.0348<$ 0.05 , sehingga $\mathrm{H}_{0}$ ditolak dan $\mathrm{H}_{1}$ diterima yang berarti variable pesan instan secara parsial berpengaruh signifikan dan positif terhadap variable pendapatan e-commerce.

Dengan demikian, berdasarkan nilai coefficient yang tertera pada tabel output, didapatkan persamaan regresi linier berganda seperti berikut ini : $\mathrm{Y}=135,193+(-1,065 * \mathrm{X} 1)+(-0,320 * \mathrm{X} 2)+(-$

$0,073 * \mathrm{X} 3)+(-0,330 * \mathrm{X} 4)$

Berdasarkan rumus persamaan regresi linier berganda di atas, maka dapat disimpulkan hal-hal sebagai berikut :

1. Terdapat nilai konstanta positif sebesar 135,193 , sehingga dapat dinyatakan bahwa nilai variabel independen dianggap konstan, maka rata-rata pendapatan naik sebesar 135.193 persen.

2. Nilai koefisien website adalah sebesar -1.065, dengan nilai koefisien yang negatif dan asumsi mengabaikan variabel bebas lainya menunjukkan bahwa website memiliki pengaruh negatif terhadap pendapatan e-commerce, sehingga bila pendapatan e-commerce meningkat sebesar 1 persen maka mengakibatkan penurunan pendapatan e-commerce sebesar 1.065 persen.

3. Nilai koefisien marketplace/digital platform adalah sebesar -0.320, dengan nilai koefisien yang negatif dan asumsi mengabaikan variabel bebas lainya menunjukkan bahwa marketplace/digital platform memiliki pengaruh negatif terhadap pendapatan e-commerce, sehingga bila pendapatan e-commerce meningkat sebesar 1 persen maka menurunkan pendapatan $e$ commerce sebesar 0.320 persen.

4. Nilai koefisien media sosial adalah sebesar 0.073 , dengan nilai koefisien yang negatif dan asumsi menunjukkan bahwa media sosial memiliki pengaruh negatif terhadap pendapatan $e$ commerce, sehingga bila pendapatan e-commerce meningkat sebesar 1 persen maka menurunkan pendapatan e-commerce sebesar 0.073 persen.

5. Nilai koefisien pesan instan adalah sebesar 0.330 , dengan nilai koefisien yang negatif dan asumsi mengabaikan variabel bebas lainya menunjukkan bahwa pesan instan memiliki pengaruh negatif terhadap pendapatan $e$ commerce, sehingga bila pendapatan $e$-commerce meningkat sebesar 1 persen maka menurunkan pendapatan $e$-commerce sebesar 0.330 persen,

\section{KESIMPULAN}

Sebesar 64.08 persen variabel independen (website, marketplace/digital platform, media sosial, dan pesan instan) mempengaruhi variable dependen (pendapatan e-commerce). Variabel-variabel independen terbukti secara bersama-sama berpengaruh signifikan terhadap variable dependen. Secara parsial, masing-masing variabel independen yaitu website, marketplace/digital platform, dan pesan instan memiliki pengaruh yang signifikan terhadap pendapatan yang di dapat melalui $e$ commerce, namun tidak dengan variabel media sosial. Keempat variabel independen yang digunakan sebagai saluran distribusi/media penjualan merupakan media penjualan yang tepat bagi pelaku usaha untuk meningkatkan pendapatan e-commerce. Tidak signifikannya variabel media sosial secara parsial terhadap peningkatan pendapatan $e$-commerce disebabkan karena transaksi yang dilakukan melalui media sosial dialihkan menjadi transaksi melalui marketplace/digital platform. Pengalihan transaksi ini disebabkan kurangnya kepercayaan pembeli bila melakukan transaksi secara langsung kepada penjual sehingga pembeli memerlukan pihak lain yang lebih dapat dipercaya oleh pembeli sebagai media transaksi.

\section{REFERENSI}

Agung, Di. T. (2020). Metodologi Penelitian Panduan Lengkap Penelitian dengan Mudah 
(Giovanni (ed.); 1st ed.). Andi.

Akhmad, S. (2014). Redefinisi Bauran Pemasaran (Marketing Mix) "4P" Ke "4C." Journal of Applied Business and Economics, 1, 17-23. https://journal.lppmunindra.ac.id/index.php/JA BE/article/viewFile/1360/1084

Akram, W., \& Kumar, R. (2017). A Study on Positive and Negative Effects of Social Media on Society. International Journal of COmputer Sciences and Engineering, 5(10), 347-354. https://www.researchgate.net/publication/3239 03323_A_Study_on_Positive_and_Negative_ Effects_of_Social_Media_on_Society

Ayuni, Q., Cangara, H., \& Arianto. (2019). Pengaruh Penggunaan Media Digital Terhadap Tingkat Penjualan Produk Kuliner Kemasan. Jurnal Penelitian Komunikasi Dan Opini Publik, 23 No. 2, 129-141. https://jurnal.kominfo.go.id/index.php/jpkop/a rticle/view/2382

Eko, S., Mariani, S., \& Sugiman. (2017). Perbandingan Metode Partial Least Sqaure (PLS) Dan Principal Component Regression (PCR) Untuk Mengatasi Multikolinearitas Pada Model Regresi Linear Berganda. UNNES Journal of Mathematics, 6(2), 117-128. https://journal.unnes.ac.id/sju/index.php/ujm/a rticle/view/11819

Grieger, M. (2003). Electronic marketplaces: A literature review and a call for supply chain management research. European Journal of Operational Research, 280-294. https://core.ac.uk/download/pdf/208724007.pd $\mathrm{f}$

Hari, Moch Purwidiantoro, S.W., D. F. K., \& Hadi, W. (2016). Pengaruh Penggunaan Media Sosial Terhadap Pengembangan Usaha Kecil Menengah (UKM). Jurnal EKA CIDA, 1(1), 30-39.

https://journal.amikomsolo.ac.id/index.php/ek acida/article/viewFile/19/11

Lind, A. D., Marchal, W. G., \& Wathen, S. A. (2014). Teknik-Teknik Statistika dalam Bisnis dan Ekonomi (15 Buku I). Salemba Empat.

Luthfi, A. K., Anggraini, N. R., Syakilah, A., Citra, V. W., Untari, R., \& Sutarsih, T. (2021). Statistik E-Commerce 2020. https://www.bps.go.id/publication/2020/12/24/ 2548417ddc6dab8247553124/statistik-ecommerce-2020.html

Marita, W. E. (2015). Pengaruh Struktur Organisasi Dan Ukuran Perusahaan Terhadap Penerapan Business Entity Concept. AKRUAL Jurnal Akuntansi, 7(1), 18-40.

OJK. (2008). Undang-Undang Republik Indonesia No. 20 Tahun 2008 Tentang Usaha Mikro, kecil dan Menengah. 2008.

Rustam, M. (2017). Internet Dan Penggunaannya (Survei di Kalangan Masyarakat Kabupaten Takalar Provinsi Sulawesi Selatan). Jurnal
Studi Komunikasi Dan Media, 21 No. 1, 13-24. https://doi.org/10.17933/jskm.2017.210102

Ryan, T. P. (1997). Modern Regression Methods. John Wiley \& Sons.

Sriningsih, M., Hatidja, D., \& Prang, J. D. (2018). Penanganan Multikolinieritas Dengan Menggunakan Analisis Regresi Komponen Utama Pada Kasus Impor Beras Di Provinsi Sulut. Jurnal Ilmiah Sains, 18(1). https://ejournal.unsrat.ac.id/index.php/JIS/artic le/view/19396

Sukmono, A. (2014). Penggunaan Partial Least Square Regression (PLSR) untuk Mengatasi Multikolinearitas Dalam Estimasi Klorofil Daun Tanaman Padi dengan Citra Hiperspektral. Program Studi Teknik Geodesi, Fakultas Teknik, Universitas Diponegoro.

Trimarsiah, Y., \& Arafat, M. (2017). Analisis Dan Perancangan Website Sebagai Sarana Informasi Pada Lembaga Bahasa Kewirausahaan Dan Komputer Akmi Baturaja. Jurnal Ilmiah MATRIK, Vol.19 No., 1-10. https://media.neliti.com/media/publications/22 4989-analisis-dan-perancangan-websitesebagai-8f2cd456.pdf 